Epidemiology and Psychiatric

Sciences

cambridge.org/eps

\section{Contemporary Outsider Art}

This Section of Epidemiology and Psychiatric Sciences appears in each issue of the Journal and is dedicated to all forms of creative production born of an intimate and individual urge, often secretive, unbound from the conventional art system rules. Through short descriptions of the Outsider art work of prominent artists and new protagonists often hosted in community mental health services, this Section intends to investigate the latest developments of the contemporary art scene, where the distances between the edge and the centre are becoming more and more vague. Carole Tansella, Section Editor

Cite this article: Rieger $\mathrm{H}$ (2019). The inverted dragon. Epidemiology and Psychiatric Sciences 28, 603-604. https://doi.org/10.1017/ S2045796019000490

Received: 26 July 2019

Accepted: 31 July 2019

First published online: 11 September 2019

Author for correspondence:

Hannah Rieger, E-mail: hannah.rieger@

livinginartbrut.com

\title{
The inverted dragon
}

Hannah Rieger

Vienna, Austria

Drawing is Laila Bachtiar's driving force and main purpose in life. It was in 1975, aged four, that she began to draw regularly. At that stage she did not speak at all. Her mother, a cellist, liked to take her along to orchestral rehearsals in Vienna, where she would lie on the floor for hours, drawing. In later life there were phases when in the social institutions where she lived, she was forbidden to draw. Her reaction was immediate, startling and physical.

Laila Bachtiar's creative work depicts two different worlds (Feilacher, Ansperger, 2018), a colourful one and a grey one, because she uses either coloured or black pencils. The two worlds are linked in origin, since they result from the same specific technique developed by the artist. She uses strong pencil strokes to outline her chosen subject swiftly and assertively. Her main theme is the organic universe.

Laila Bachtiar then adds a net-like structure, a kind of framework formed of lines and spaces. She uses dynamic strokes to form shapes and sections, building up the subject in this way. The resulting outlines are then filled using coloured or graphite pencil. This brings a sense of order to each individual drawing, through this distinctively structured style composed of lines and spaces. Order is in itself an important element of life for the artist.

It takes Laila Bachtiar a long time to shade in the individual elements: she draws with tremendous patience and perseverance, placing lines side-by-side and across each other. Drawing is like an act of devotion to her creative process, that comes from her innermost being. While she is drawing she seems in complete harmony with herself.

'Krokodil Laila auf' (see Fig. 1) is a self-portrait of the artist (see Fig. 2). She is shown weaponless, riding a mighty archaic animal that makes me think of a dragon, and gives an impression of great power. The result of her constructional, structuring technique is plainly visible. The fearsome wild animal seems to have been tamed by the artist herself, deconstructed and reconstructed from colourful component parts. Perhaps she sees this inverted dragon as an appropriate counterpart to her autistic communication. A friend in the universe.

Laila Bachtiar's compositions have a dynamic intensity and tension. The resulting effect is an almost fabric-like texture, giving her subjects a striking physicality. Some of her drawings are reminiscent of woven rugs, even when they depict animals, trees, or people. In her grey works, she gives free rein to the pencil, making the most of its potential in all its facets.

As a woman artist, Laila Bachtiar is the pioneer of the Gugging Austrian Art Brut model: She first came to the House of Artists in 1990, as the first female artist in residence (Feilacher, 2004), where she drew intermittently, but over a long period. Since 2003 she has been working regularly at Atelier Gugging, which provides a structured daily routine for artists who are not resident at Gugging. Laila Bachtiar has returned to live with her mother in Vienna, after a long history of special schools and residential communities in various social institutions.

From the 1950s onwards, the Austrian psychiatrist Leo Navratil supported patients of what was then the psychiatric clinic in Maria Gugging, in their artistic development. In 1965 he published his first book (Navratil, 1965), and in 1969 he sent some drawings to Jean Dubuffet, requesting an artistic assessment. Dubuffet confirmed Navratil's view of the Gugging artists' talents from an Art Brut perspective. So began the Austrian tradition of using the term Art Brut, rather than Outsider Art. In 1981, Leo Navratil founded the House of Artists, as a men's institution, in an empty pavilion in the grounds of the clinic. In 2007 this artists' community became a social welfare institution. Johann Feilacher, Leo Navratil's successor, developed Gugging further, into a globally unique Art Brut centre, with art production facilities (House of Artists and studio), a gallery, and a museum, which opened in 2006.

Since 2013 (Feilacher, 2013; Feilacher, 2014) Laila Bachtiar's works have been shown there in group exhibitions. In the 2018 exhibition 'gehirngefühl.!' (Feilacher and Ansperger, 2018), for the first time an entire room was dedicated to Laila Bachtiar and the Gugging star Oswald Tschirtner. With nine works by Laila Bachtiar on display, it was clear to the public that the previously male domain of Gugging was now open to women. With nine works again, Laila Bachtiar was included amongst 93 female artists in the 2019 exhibition, 'Flying High' (Brugger et al., 2019) in Vienna's Kunstforum.

As well as drawing, Laila Bachtiar loves to visit exhibitions where her own works are displayed (Rieger and Dobner, 2018). Dignified and distant, she sometimes takes selected visitors by the hand and proudly shows them her work. 


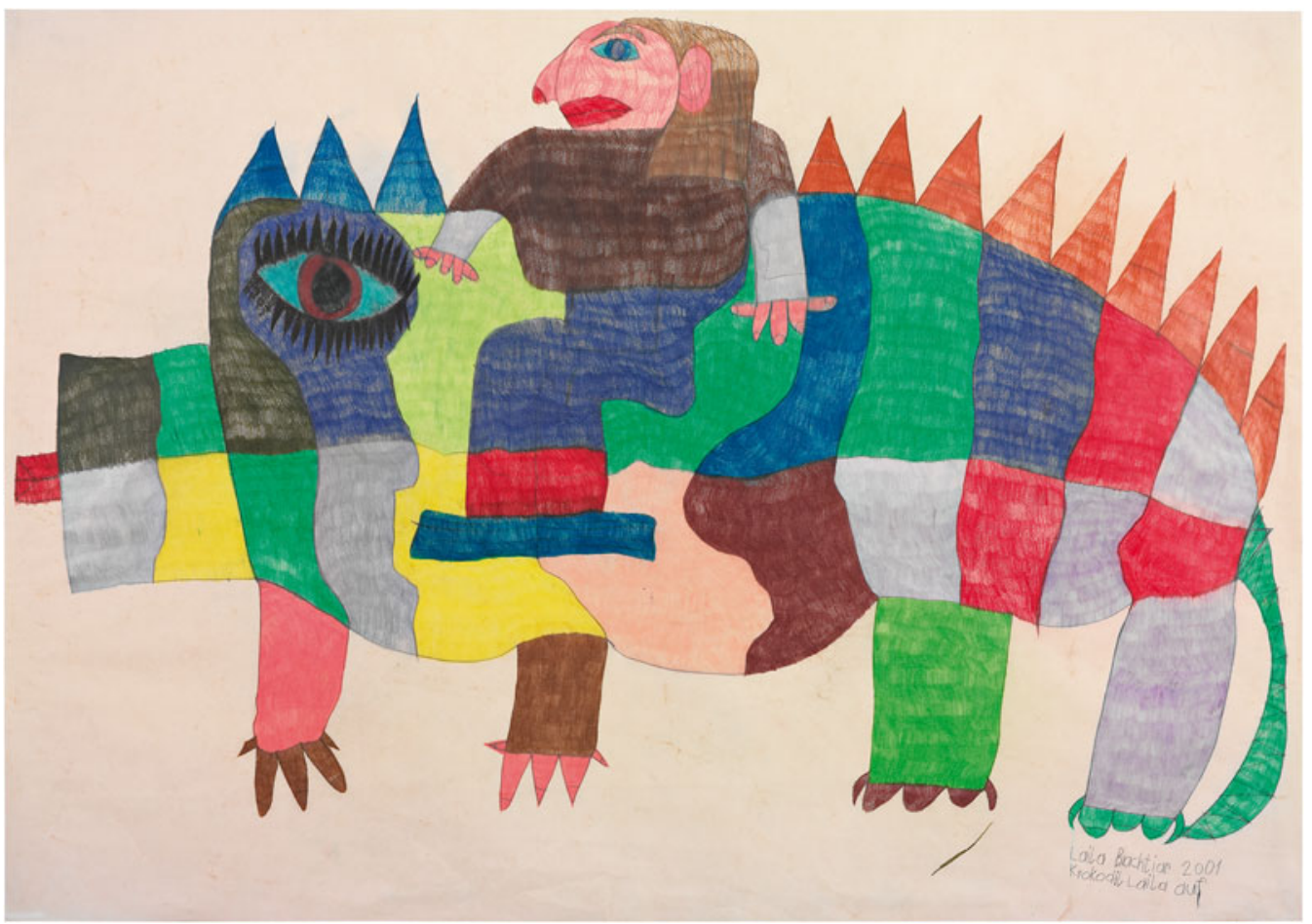

Fig. 1. Laila Bachtiar, Krokodil Laila auf, $2001,70 \times 100$ cm, pencil, coloured pencils, Hannah Rieger Collection, c galerie gugging, Photo by Detailsinn Fotowerkstatt.

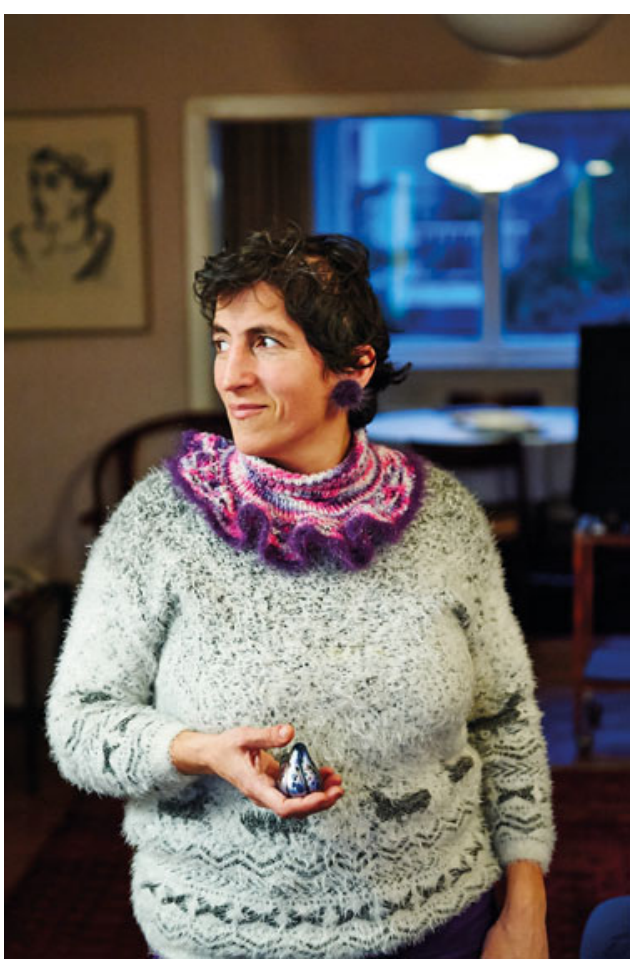

Fig. 2. Laila Bachtiar, Photo by Aleksandra Pawloff.

\section{References}

Brugger I, Rieger H and Rudorfer V (eds) (2019) Flighing High. Künstlerinnen der Art Brut. Heidelberg, Berlin: Kehrer.

Feilacher J (ed.) (2004) SOVÄREN. Das Haus der Künstler in Gugging. Heidelberg: Edition Braus.
Feilacher J (ed.) (2013) Small Formats. St. Pölten, Salzburg: Residenz Verlag. Feilacher J (ed.) (2014) gugging meisterwerke.!. St. Pölten, Salzburg: Residenz Verlag.

Feilacher J and Ansperger N (eds) (2018) gehirngefühl!! Kunst aus Gugging von 1970 bis zur Gegenwart. Salzburg - Wien: Residenz Verlag.

Navratil L (1965) Schizofrenie und Kunst. München: dtv.

Rieger H and Dobner H (eds) (2018) Living in Art Brut. 123 Works From the Hannah Rieger Collection. Wien: GLOBART.

About the author. Hannah Rieger was born in Vienna in 1957 and completed a degree in economics at the University of Vienna. After a short period working as a university assistant at the University of Vienna, she joined the specialist banking group Investkredit in 1983, where she worked until 2010 in various functions including Director of Marketing and Corporate Communications. For many years, Hannah Rieger has been working as an independent consultant for professional development (group dynamics trainer at the Austrian Association of Group Psychotherapy and Group Dynamics - OeAGG, and supervisor and coach with OeAGG and the Austrian Association for Supervision and Coaching - OeVS).

She is also the author and editor of a number of professional publications on topics such as corporate subsidies and family businesses. In 2014 she published her first work on Art Brut - 'Kunst, die verbindet' (United in Art) - through AQ-Verlag, Vienna. The Globart book catalogue 'Living in Art Brut. 123 Works from the Hannah Rieger Collection' followed in 2017.

In 2018/2019 the Art et Marges musée, Brussels, showed 105 works from her collection ('Les Femmes dans l' art brut?'). Hannah Rieger curated together with Ingried Brugger 'Flying High. Female Art Brut Artists' in 2019 at the Kunstforum Vienna and is co-editor of the bookcatalogue.

She also works as a lecturer and moderator, e.g. on art topics. From 2008 to 2018, Hannah Rieger was a member of the University Council at the University of Applied Arts Vienna, and from 2013 to 2018 is Deputy Chairwoman.

Hannah Rieger has been collecting Art Brut since 1991.

Carole Tansella, Section Editor 